Journal of Health Promotion and Behavior (2018), 3(1): 16-26

https://doi.org/10.26911/thejhpb.2018.03.01.02

\title{
Health Belief Model on the Determinants of Human Papilloma Virus Vaccination in Women of Reproductive Age in Surakarta, Central Java
}

\author{
Yulia Fitriani,1,2), Ambar Mudigdo3), Rita Benya Andriani4) \\ 1) School of Health Sciences Ganesha Husada, Kediri, East Java \\ ${ }^{2)}$ Masters Program in Public Health, Universitas Sebelas Maret \\ 3)Faculty of Medicine, Universitas Sebelas Maret \\ 4)School of Health Polytechnics, Surakarta
}

\begin{abstract}
Background: Cervical cancer is a type of cancer that develops in a woman's cervix. Cervical cancer is caused by a human papillomavirus (HPV). Cervical cancer ranked fourth against most women's cancer. The incidence of cervical cancer was estimated at 528,000 (7.9\%) cases worldwide causing 266,000 deaths in 2012. The HPV vaccine can protect women from HPV infection, thus lowering the risk of cervical cancer. This study aimed to analyze the determinants of HPV vaccination in women of reproductive age in Permata Harapan Oncology Clinic, Surakarta, Central Java, using Health Belief Model.

Subjects and Method: This was an analytic observational study with a case-control design. This study was conducted at Permata Harapan Oncology Clinic, Surakarta, from January to February 2018. A total study of 200 study subjects was selected by fixed disease sampling. The dependent variable was HPV vaccination. The independent variables were knowledge, perceived seriousness, perceived susceptibility, perceived barrier, perceived benefit, family income, and family support. The data were collected by questionnaire and analyzed by a multiple logistic regression.

Results: HPV vaccination increased with better knowledge $(\mathrm{OR}=7.97 ; 95 \% \mathrm{CI}=1.50$ to $42.38 ; \mathrm{p}=$ 0.015), perceived seriousness $(\mathrm{OR}=22.81 ; 95 \% \mathrm{CI}=6.06$ to 85.86 ; $\mathrm{p}<0.001)$, perceived susceptibility $(\mathrm{OR}=4.03 ; 95 \% \mathrm{CI}=1.25$ to $13.09 ; \mathrm{p}=0.020)$, perceived benefit $(\mathrm{OR}=6.57 ; 95 \% \mathrm{CI}=1.88$ to 22.98; $\mathrm{p}=0.003)$, family income $(\mathrm{OR}=5.32 ; 95 \% \mathrm{CI}=1.57$ to $18.07 ; \mathrm{p}=0.007)$, and family support $(\mathrm{OR}=6.86 ; 95 \% \mathrm{CI}=1.55$ to $30.36 ; \mathrm{p}=0.011)$. $\mathrm{HPV}$ vaccination decreased with perceived barrier $(\mathrm{OR}=0.14 ; 95 \% \mathrm{CI}=0.04$ to $0.51 ; \mathrm{p}=0.003)$.

Conclusion: HPV vaccination increases with better knowledge perceived seriousness, perceived susceptibility, perceived benefit, family income, and family support, but decreases with perceived barrier.
\end{abstract}

Keywords: HPV vaccination, knowledge, perceived seriousness, perceived susceptibility, perceived barrier, perceived benefit, family income, family support

\section{Correspondence:}

Yulia Fitriani. Masters Program in Public Health, Sebelas Maret University, Jl. Ir. Sutami 36 A, Surakarta 57126, Central Java. Email: yuliafitriani38@gmail.com. Mobile: 085655708946.

\section{BACKGROUND}

Cervical cancer is still a problem related to women's health in Indonesia, this is because of the high prevalence and mortality. The late diagnosis when it has already been at an advanced stage, weak common condition, low socioeconomic status, limited resources, limited facilities and infra- structure, histopathology, and educational background have roles in determining the prognosis of the patients (Rasjidi, 2009).

Cervical cancer is one type of noninfectious diseases that is chronical and in most cases is caused by Human Papilloma Virus (HP-V). More than 100 types of HPV have been identified, clinically it is classi- 
fied into two groups: high-risk and low-risk viruses (Mahendra, 2012). Cervical cancer is the fourth most common cancer in women, after breast, colorectal and lung cancer. It is estimated that there were 528,000 (7.9\%) of cervical cancer new cases worldwide and caused 266,000 deaths or $7.5 \%$ of all female cancer deaths in 2012 (Globocan, 2012).

The prevalence of cancer in Indonesia was 1.4 per 1 ,000 population and this was number 7 cause of death (5.7\%) of all causes (Ministry of Health, 2013). Cervical cancer and breast cancer were the highest prevalence of cancer in Indonesia in 2013, namely cervical cancer of $0.8 \%$ o and breast cancer of $0.5 \%$. Riau Islands Province, North Maluku Province and Special Region of Yogyakarta have the highest prevalence of cervical cancer, which was $1.5 \%$, whereas the prevalence of breast cancer was the highest in Yogyakarta Province, which was $2.4 \%$. For the estimation of the number of cervical cancer patients, Central Java was in the second place after East Java with about 19.734 patients (Ministry of Health, 2015).

The high mortality rate caused by cervical cancer can be reduced globally through a comprehensive approach, including prevention, early diagnosis, effective screening and treatment programs. Currently, there is a vaccine that protects against common causes of cancer Human Papilloma Virus and can significantly reduce the risk of cervical cancer (WHO, 2016). Prophylactic vaccine will work efficiently if the vaccine is given before someone is exposed to HPV infection. The starting vaccine can be given to women aged 10 years, after menstruation. According to the recommendation of the Food and Drug Administration United States (FDA US) HPV vaccine can be given to women aged 10-26 years (Setiawati,
2014). The HPV vaccine may be beneficial for sexually active women because of their ongoing risk of getting new HPV infections and the development of Cervical Intraepithelial Neoplasia (CIN) and cervical cancer. Clinical trial data show that the ASo4-adjuvanted HPV-16/18 vaccine is safe and immunogenic in 55-year-old women, while preliminary data with quadrivalent vaccine show evidence of safety, immunogenicity and high benefits in women 24 to 45 years. HPV vaccinations in women over 25 years have been approved in some countries, and these women individually seek advice on vaccinations from health personnel (Castellsagué et al., 2009).

Based on some previous research, there are many factors related to HPV vaccination. The Wilson et al (2016) study aiming at assessing demographic and attitudinal factors related to HPV vaccine in women aged 18 to 26 in Utah suggesting that the variables associated with the HPV vaccine include, among others, younger ages of 22 years, marital status, awareness of HPV deployment, knowledge of the relationship between HPV and cervical cancer, confidence in the importance of vaccines for prevention and physician recommendations. Canfell et al. (2015) stated that birthplace (Australia), marital status, alcohol use, contraceptive use, and high socioeconomic status were associated with HPV vaccine acceptance. Another study conducted by Tung (2016) shows that factors related to HPV vaccine acceptance include birth place (Australia), family support (parents) and cervical cancer vaccine safety.

Nowadays, some private hospitals are already providing HPV vaccination, however the facility is not followed by the number of women in reproductive age who are vaccinated. This might be because of several factors including the lack of know- 
Journal of Health Promotion and Behavior (2018), 3(1): 16-26

https://doi.org/10.26911/thejhpb.2018.03.01.02

ledge, economic ability, and family support. In addition to these factors, there is an influential mother's behavior factor that is the individual's readiness to change the behavior in order to avoid a disease or minimize health risks. The motivation in an individual environment to change the behavior and the behavior itself through the Health Belief Model (HBM). Health Belief Model states that a person's behavior is affected by: 1) susceptibility to perceived illness, 2) seriousness which is felt, 3 ) perceived benefit, 4) perceived barriers, 5) cues to action, 6) self-efficacy (Becker and Rosenstock, 1987). In this study, the researchers wanted to know whether there is a relationship between the determinants of behavior reviewed by precede proceeding theory and Health Belief Model on HPV vaccination in women in their reproductive age.

This study was conducted at the Main Clinic of Permata Harapan Surakarta Oncology because the clinic was the main cancer clinic in Surakarta and has been providing HPV vaccination. Based on the preliminary study conducted by researchers at the Main Clinic of Permata Harapan Surakarta Oncology, the number of women in reproductive age who did HPV vaccination in 2015 was 640. In 2016, there were 550 people and in January-April 2017, there were 219 people. Based on the background, the author interest to analyze the determinants of HPV vaccination behavior (Human Papilloma Virus) in women of reproductive age at oncology clinic at Permata Harapan, Surakarta, Central Java.

\footnotetext{
SUBJECTS DAN METHOD

\section{Study Design}

This was an analytic observasional with a case control design. The study was conducted at Permata Harapan Oncology Clinic, Surakarta, from January to February 2018.
}

\section{Population and Sample}

Population sources in the study were all women in reproductive age aged 15-49 years who came to Permata Harapan Oncology Clinic, Surakarta. A total of 200 study subjects selected using fixed disease sampling, included 100 women who did HPV vaccination (case) and those who did not vaccinate HPV (control).

\section{Study variables}

The dependent variable was HPV vaccination behavior, meanwhile the the independent variables were knowledge, family income, family support, perception of seriousness, perception of vulnerability, perception of barriers and perception of benefits.

\section{Operational definition of variables}

HPV vaccination behavior was defined as the subject of HPV vaccination. Knowledge is everything the subject knows about cervical cancer in terms of definition, etiology, stages, symptoms, risk factors and also the prevention HPV vaccine.

Family income was defined as the income as a result of economic processes or cumulative economic resources of the family members (husband, wife, and children) within a month.

Family support was defined as the support, assistance or attention given by the family to the subject for vaccinating HPV.

Perceived seriousness was defined as the perception or opinion of the subject about the seriousness of the cervical cancer. Vulnerability perception is the perception / opinion of the subject about the level of risk and the impact of cervical cancer.

Perceived barrier was defined as an obstacle is faced by the subjects in the process of HPV vaccination including cost, discomfort, vaccine safety perception, and the side effects. 
The perceived benefit was defined as the positive impact of the subject from the HPV vaccination that includes protection against cervical cancer.

\section{Data Analysis}

A multiple logistic regression were employed for data analysis..

\section{Research Ethics}

This study has granted the ethical approval from the medical research ethic com-

Table 1. Sample characteristics

\begin{tabular}{lcc}
\hline \multicolumn{1}{c}{ Characteristics } & n & \% \\
\hline Age & & 58 \\
$<35$ years old & 116 & 42 \\
$\geq 35$ years old & 84 & \\
Education & & 17 \\
Low <Senior high school & 34 & 83 \\
High $\geq$ Senior high school & 166 & \\
Occupation & & 23 \\
Jobless & 46 & 77 \\
Working & 154 & \\
Marital Status & & 13 \\
Single & 26 & 87 \\
Married & 174 & \\
\hline
\end{tabular}

Table 2 shows that out of the 200 subjects, half of them did not get the vaccination (50\%) and half of them got HPV vaccination (50\%). Most of the subjects were well-informed (64\%) and mission of Dr. Moewardi Hospital, Surakarta.

\section{RESULTS}

\section{Sample characteristics}

The characteristics of the research subjects in Table 1 indicated that the majority of them were $\geq 35$ years old (58\%), highly educated (83\%), employed (77\%), and married (87\%).

Table 2. Univariate Analysis

\begin{tabular}{|c|c|c|c|}
\hline Variable & Category & $\mathbf{N}$ & $\%$ \\
\hline \multirow[t]{2}{*}{ HPV vaccination behaviour } & No & 100 & 50 \\
\hline & Yes & 100 & 50 \\
\hline \multirow[t]{2}{*}{ Knowledge } & Low & 72 & 36 \\
\hline & High & 128 & 64 \\
\hline \multirow[t]{2}{*}{ Family income } & Low & 93 & 46.5 \\
\hline & High & 107 & 53.5 \\
\hline \multirow[t]{2}{*}{ Family support } & Weak & 77 & 38.5 \\
\hline & Strong & 123 & 61.5 \\
\hline \multirow[t]{2}{*}{ Perceived seriousness } & Low & 99 & 49.5 \\
\hline & High & 101 & 50.5 \\
\hline \multirow[t]{2}{*}{ Perceived susceptibility } & Low & 95 & $47 \cdot 5$ \\
\hline & High & 105 & 52.5 \\
\hline \multirow[t]{2}{*}{ Perceived barriers } & Low & 115 & 57.5 \\
\hline & High & 85 & 42.5 \\
\hline \multirow[t]{2}{*}{ Perceived benefit } & Low & 88 & 44 \\
\hline & High & 112 & 56 \\
\hline
\end{tabular}

$36 \%$ had poor knowledge. As many as $53.5 \%$ study subjects had high family income. As many as $46.5 \%$ study subjects had low income. As many as $61.5 \%$ study subjects received strong family support. 
Journal of Health Promotion and Behavior (2018), 3(1): 16-26

https://doi.org/10.26911/thejhpb.2018.03.01.02

Most of the subjects had a high perceived seriousness (50.5\%). As many as 49.5\% study subjects had a low perceived seriousness. Most subjects had a high susceptibility perception (52.5\%) and a small percentage had a low susceptibility perception (47.5\%). Most subjects had a small perception of barriers (57.5\%) and a small percentage had a great seriousness perception (42.5). Most of the subjects had a large benefit perception (56\%) and a

Table 3. Bivariate analysis of determinants of HPV vaccination behavior in Women in Reproductive Age

\begin{tabular}{|c|c|c|c|c|c|c|c|c|}
\hline \multirow{3}{*}{ Independent Variable } & \multicolumn{4}{|c|}{$\begin{array}{c}\text { HPV Vaccination } \\
\text { Behaviour }\end{array}$} & \multirow{3}{*}{$\mathbf{O R}$} & \multicolumn{2}{|c|}{ CI $95 \%$} & \multirow{3}{*}{ p } \\
\hline & \multicolumn{2}{|c|}{ No } & \multicolumn{2}{|c|}{ Yes } & & \multirow{2}{*}{$\begin{array}{l}\text { Upper } \\
\text { Limit }\end{array}$} & \multirow{2}{*}{$\begin{array}{l}\text { Lower } \\
\text { Limit }\end{array}$} & \\
\hline & $\mathbf{n}$ & $\%$ & $\mathbf{n}$ & $\%$ & & & & \\
\hline \multicolumn{9}{|l|}{ Knowledge } \\
\hline Poor & 64 & 88.9 & 8 & 11.1 & 20.44 & 8.92 & 46.88 & $<0.001$ \\
\hline Good & 36 & 28.1 & 92 & 71.9 & & & & \\
\hline \multicolumn{9}{|l|}{ Family Income } \\
\hline Low & 66 & 71 & 27 & 29 & 5.25 & 2.87 & 9.61 & $<0.001$ \\
\hline High & 34 & 31.8 & 73 & 68.2 & & & & \\
\hline \multicolumn{9}{|l|}{ Family Support } \\
\hline Weak & 69 & 89.6 & 8 & 10.4 & 25.60 & 11.08 & 59.14 & $<0.001$ \\
\hline Strong & 31 & 25.2 & 92 & 74.8 & & & & \\
\hline \multicolumn{9}{|l|}{$\begin{array}{l}\text { Perseption of } \\
\text { seriousness }\end{array}$} \\
\hline Low & 82 & 82.8 & 17 & 17.2 & 22.24 & 10.72 & 46.14 & $<0.001$ \\
\hline High & 18 & 17.8 & 83 & 82.2 & & & & \\
\hline \multicolumn{9}{|l|}{$\begin{array}{l}\text { Perceived } \\
\text { susceptibility }\end{array}$} \\
\hline Low & 71 & 74.7 & 24 & $25 \cdot 3$ & $7 \cdot 75$ & 7.75 & 14.56 & $<0.001$ \\
\hline High & 29 & 27.6 & 76 & 72.4 & & & & \\
\hline \multicolumn{9}{|l|}{ Perceived barriers } \\
\hline Low & 35 & 30.4 & 80 & 69.6 & 0.13 & 0.07 & 0.25 & $<0.001$ \\
\hline High & 65 & 76.5 & 20 & 23.5 & & & & \\
\hline \multicolumn{9}{|l|}{ Perceived benefit } \\
\hline Low & 67 & 76.1 & 21 & 23.9 & 7.63 & 4.04 & 14.44 & $<0.001$ \\
\hline High & 33 & 29.5 & 79 & 70.5 & & & & \\
\hline
\end{tabular}

\section{Multivariate Analysis}

Table 4 shows that there is a significant relationship between HPV vaccination behavior with knowledge, family income, family support, perceived seriousness, perceived vulnerability, perceived barriers, and perceived benefits. HPV vaccination behavior was associated with knowledge (OR= 7.97; $95 \% \mathrm{CI}=1.50$ to $42.38 ; \mathrm{p}=0.015)$, small percentage had a small benefit perception (44\%).

\section{Bivariate Analysis}

Bivariate analysis describes the relationship of knowledge, family income, family support, perceptions of seriousness, perceptions of vulnerability, perception of barriers and beneficial perceptions and the behavior of HPV vaccination using ChiSquare test. 
Fitriani et al./ Health Belief Model on the Determinants of Human Papilloma

Table 4. The results of multivariate analysis on the of HPV vaccination behavior determinants by multiple logistic regression test

\begin{tabular}{lcccc}
\hline \multirow{2}{*}{\begin{tabular}{l} 
Independent Variabel \\
\cline { 3 - 4 }
\end{tabular}} & OR & Lower Limit & $\begin{array}{c}\text { Upper } \\
\text { Limit }\end{array}$ & p \\
\hline Knowledge (good) & 7.97 & 1.50 & 42.38 & 0.015 \\
Family Income ( $\geq$ Rp 5,000,000) & 5.32 & 1.57 & 18.07 & 0.007 \\
Family Support (strong) & 6.86 & 1.55 & 30.36 & 0.011 \\
Perceived seriousness (high) & 22.81 & 6.06 & 85.86 & 0.000 \\
Perceived susceptibility (high) & 4.03 & 1.25 & 13.09 & 0.020 \\
Perceived barriers (high) & 0.14 & 0.04 & 0.51 & 0.003 \\
Perceived benefit (high) & 6.57 & 1.88 & 22.98 & 0.003 \\
N observation = 200 & & & & \\
Nagelkerke R Square $=83.60 \%$ & & & & \\
-2 Log likelihood = 79.87 & & & & \\
\hline
\end{tabular}

\section{DISCUSSION}

\section{The relationship between the level of knowledge and HPV vaccination}

The result of the study showed that there was a relationship between knowledge and HPV vaccination which is statistically significant. A high level of knowledge increased the HPV vaccination by 7.97 times than the low level of knowledge.

Knowledge is the result of knowing that occurs after people sense a particular object. Knowledge is one of the most important aspects in forming the attitudes and behaviours. It will be easier to accept new behaviours if it is based on the right knowledge, awareness, and positive attitudes (Notoatmodjo, 2007).

This is in line with the ideas from Sari and Syahrul (2014) who stated that women who got HPV vaccination for about $76 \%$ had a high level of knowledge, while women who did not get the vaccination, mostly have moderate and low level of knowledge. This indicated that women with high level of knowledge are more likely to have HPV vaccination compared to women with moderate or intermediate knowledge. The score of statistic test is $\mathrm{p}=0.001$, which means that there was a relationship between the level of knowledge and HPV vaccinations.
This study is supported by the previous research done by Jones dan Cook (2008), which stated that knowledge of the causal relationship between HPV infection and cervical cancer has an impact on the decision making in cervical cancer prevention behavior, which are in sexual behavior, screening for cervical cancer and HPV vaccination. Study subjects who had higher knowledge about HPV vaccination had 3.59 times greater to recieve HPV vaccination than those who answered o or 1 question only.

\section{The relationship between family} income and HPV vaccination

The result of this study showed that there was a relationship between family income and HPV vaccination which is statistically significant. High family incomes increased HPV vaccination for about 5.32 times compared to those who have low family incomes.

The level of income is one of the resources that affect people to have a healthy behaviour. This is because adequate income levels provide greater possibilities to come to the health facilities and get medical check ups (Notoatmodjo, 2007).

According to Al-Naggar and Bobryshev (2011), women with high monthly income were more likely to have HPV 
Journal of Health Promotion and Behavior (2018), 3(1): 16-26

https://doi.org/10.26911/thejhpb.2018.03.01.02

vaccination due to the high cost of HPV vaccination. Similar study was conducted by Canfell et al. (2015), which stated that high income has positive effect on HPV vaccination in 18-16 years old American women.

Family income is a supporting factor for a person to perform healthy behaviour. Family income also determines the socioeconomic status of the family. The result of this study showed that research subjects who did not get HPV vaccination were mostly from low-income families, while the majority of them who get HPV vaccination were from high-income families.

\section{The relationship between family support and HPV vaccination}

The result of this study showed that there was a relationship between family support and HPV vaccination which was statistically significant. Strong family support increased the HPV vaccination for about 6.86 times compared to those who lacked family support.

According to Friedman (2010), family support was a form of interpersonal relationship including attitudes, actions and acceptance so that family members feel cared for. Family support becomes one of the important factors to encourage someone to have healthy behaviour. Family support plays a role in forming interest and motivation. In addition, family support can provide emotional comfort to someone.

According to Sari and Syahrul (2014), family support is associated with HPV vaccination action. The strength between family support and HPV vaccination is moderate. This is in line with a study by Fiks et al (2013), which stated that family support is associated with second and third doses of vaccinations. Family plays a role in reminding (assessment support) or accompanying (instrumental support) the women to get a complete HPV vaccination. There- fore, it can be concluded that family support plays a great role in making decisions to get HPV vaccination and the fulfillment of HPV vaccination doses.

The role of husband/family is very important and strong in supporting the women in reproductive age (WRA) to conduct medical check up so that it greatly affects the status of their health. Husband/ family is the closest person to WRA in interacting and in making decisions, especially in determining the place to get the treatment. Husband/ family is a supporting factor that can affect WRA's behaviour. A well-responded husband/ family will also provide the financial support for HPV vaccination and willing to accompany the WRA to the Hospital/Clinic to do the check up.

\section{The relationship between percei- ved seriousness and HPV vaccina- tion}

The result of this study showed that there was a relationship between perceived seriousness and HPV vaccination which and statistically significant.

HBM theory which was developed by Rosenstock (1974) stated that perceived seriousness or severity of a disease can cause a person to perform a treatment effort.

According to Bakhtari et al (2012), individuals will take action to protect themselves if they consider that a person's condition is in serious trouble. Individual perception that he/she has no risk is a factor that causes women in reproductive age do not get HPV vaccination. It means that if a woman is always loyal to her partner, then she has no risk to have cervical cancer (Wilson et al., 2016). 
Fitriani et al./ Health Belief Model on the Determinants of Human Papilloma

\section{The relationship between percei- ved susceptibility and HPV vacci- nation}

The result of this study showed that there was a relationship between perceived susceptibility and HPV vaccination which is statistically significant. High perceived susceptibility increased the HPV vaccination by 22.81 times than low perceived susceptibility.

This is in line with the statement of Maulana (2009), which stated that threats or risks perceptions of disease are among the things that are associated with illness prevention. Someone who thinks that he/she has high risk of illness is more likely to do the prevention than someone who thinks that he/she has no risk of illness. High perceived susceptibility and the fear of disease severity level that may occur encourage a person to take preventions, in this case is to do HPV vaccination.

According to Sledge et al. (2013), perceived susceptibility increased the intention to get HPV vaccination. The intention to get HPV vaccination increased due to the perceptions of susceptibility on HPV infection. As stated in HBM, African and American women believed that they were more vulnerable or had higher risk of the transmission of HPV infection, therefore, they were more likely to protect themselves against the transmission by getting HPV vaccination. These findings suggest that sexual health education programs and HPV vaccination promotion should focus on the risky behaviours that affect themselves to increase HPV vaccination rates. In order to know deeper about the risks of cervical cancer, an individual must know and understand the kind of risky sexual behaviours and do the steps in avoiding the behaviours.

\section{The relationship between percei- ved barrier and HPV vaccination}

The result of this study showed that there was a relationship between perceived barrier and HPV vaccination which is statistically significant. High perceived barrier increased the HPV vaccination.

HBM theory which was developed by Rosenstock (1974) stated that perceived barrier was a potential negative consequence that may arise when taking certain actions, including physical, psychological, and financial arrangements. HBM stated that every inhibit thing will obstract the individual in certain behavioral changes, in terms of distance, cost, or other obstacles obtained from her husband and the environment. According to Al-jashamy et al. (2010), the barriers in HPV vaccination lacked awareness toward the importance of HPV vaccination, anxiety about the side effects of HPV vaccination, fear of needles, no time to get the vaccination, high cost of vaccination that cannot be afford by some people, and HPV vaccination is not necessary if a person is not sexually active.

Similar study was done by Holman et al (2014), it is stated that financial problems, parental attitudes and anxiety about the safety of HPV vaccination were the barriers of HPV vaccination. Parents often need more information before vaccinating their children. The anxiety about the effects of vaccines on sexual behavior, perceived low susceptibility to HPV infection, social influences and vaccine costs were also identified as potential barriers for parents. Some parents do not vaccinate their children because of the lack of benefits that can be felt.

Study by Farias et al (2016) has shown that the anxiety about the side effects of HPV vaccination is one of the most important factors affecting the disobedience to HPV vaccination. Anxiety 
Journal of Health Promotion and Behavior (2018), 3(1): 16-26

https://doi.org/10.26911/thejhpb.2018.03.01.02

leads to disobedience. Sledge et al. (2013) stated that perceived benefit decrease the HPV vaccination.

In this study, most of the research subjects who did not get HPV vaccination admitted that the cost of the vaccine is still too expensive, the fear of side effects, and also the lack of benefits that can be directly felt by the subjects of this study. While the subjects who do HPV vaccination recognize that the barriers are not a problem for them.

\section{The relationship between percei- ved benefit and HPV vaccination}

The result of this study showed that there was a relationship between perceived benefit and HPV vaccination which is statistically significant. High perceived benefit increased the HPV vaccination by 6.57 times than low perceived benefit.

HBM theory which was developed by Rosenstock (1974) stated that the effectiveness of the confidence level in strategies designed to reduce the threat of a disease is getting higher, therefore, the preventions will automatically be done, and in this case is to do HPV vaccination for primary prevention of cervical cancer.

In a study by Farias et al. (2016), it is stated that the parental belief that the HPV vaccination is important for their children is related to the obedience of someone in doing HPV vaccination. This is because HPV vaccine can protect the children from cervical cancer as early as possible.

According to Sledge et al. (2013), perceived benefit increase the acceptance of HPV vaccination. The perceived benefit of HPV vaccination is also a predictor of the intention to receive HPV vaccination. In getting one-time HPV vaccine injections, African-American adolescents should believe that the benefit of getting HPV vaccinations is greater than the risks. Health care providers and social work of practitioners should not only emphasize on the benefits of HPV vaccinations and the positive sexual health outcomes, but also negative HPV results. An in-depth discussion about the relationship between HPV and cancer-related needs to occur.

This is in line with a study by Schaefer et al. (2010) which stated that percieved benefit has statistically significant effect on vaccine intentions.

\section{REFERENCE}

Al-jashamy K, Al-Dubai SA, Alshagga MA, Al-Naggar RA, Baobaid MF, Tuang $\mathrm{CP}$, et al. (2010). Knowledge, attitudes and barriers for human papilloma virus (HPV) vaccines among Malaysian women. Knowledge, Attitudes and Barriers for Human Papilloma Virus (HPV) Vaccines among Malaysian Women. Asian Pac J Cancer, Vol 11: 887-892.

Al-Naggar RA, Bobryshev YV (2011). Practice towards human papillomavirus vaccine among Malaysian women: A survey of the general population.Asian Pacific Journal of Cancer Prevention, 12(8): 2045-2049.

Bakthari AF, Nuri ZR, Suhebi L (2012). Effect of Education Based on Health Belief Model on Believe Promotion and Screening Behaviours of Breast Cancer among Women Reffered to Tabriz Health Centers. Medl J Tabriz Uni Medl Sci. 2012;33:25-31.

Canfell K, Egger S, Brown JD, Velentzis LS, O'Connell DL, Banks E, .et al. (2015). Factors related to vaccine uptake by young adult women in the catch-up phase of the National HPV Vaccination Program in Australia: Results from an observational study.Vaccine, 33(20): 2387-2394. doi: 10.1016/j.vaccine.2015.01.024.

Castellsagué X, Schneider A, Kaufmann 
AM, Bosch X (2009). HPV vaccination against cervical cancer in women above 25 years of age: Key considerations and current perspectives. Gynecologic Oncology, 115(3) :S15S23.doi:10.1016/j.ygyno2009.09.021.

Farias CC, Jesus DV, Moraes HS, Butterbender IF, Martins IS, Souto MG, et al. (2016). Factors related to noncompliance to HPV vaccination in Roraima-Brazil: a region with a high incidence of cervical cancer. BMC Health Services Research, 16(1): 417. doi: 10.1186/s12913-016-1677-y.

Fiks AG, Grundmeier RW, Mayne S, Song L, Feemster K, Karavite D, et al. (2013). Effectiveness of Decision Support for Families, Clinicians, or Both on HPV Vaccine Receipt.Pediatrics, 131(6): 1114-1124.doi: 10.1542/peds.2012-3122.

Friedman M (2010). Buku Ajar Keperawatan keluarga : Riset, Teori, dan Praktek. Edisi ke-5. Jakarta: EGC.

Globocan International Agency of Cancer. (2012). Cervical Cancer. http://globocan.iarc.fr/old/FactSheets/cancers/cervix-new.asp.Accessed 27 April 2017.

Holman DM, Benard V, Roland KB, Watson M, Liddon N, Stokley S (2014). Barriers to Human Papillomavirus Vaccination Among US Adolescents. JAMA Pediatr. 2014; 168(1): 76-82.

Jones M, Cook R (2008). Intent to Receive an HPV Vaccine Among University Men and Women and Implications for Vaccine Administration. Journal of American College Health, 57(1): 2332. doi: 10.3200/JACH.57.1.23-32.

Kementerian Kesehatan RI. (2013). Riset Kesehatan Dasar 2013. Jakarta : Pusat penelitian dan Pengembangan Kesehatan (2015). Infodatin. Jakarta: Pusat
Data dan Informasi Kemenkes RI

Mahendra NB (2012). Vaksin Human Papillomavirus. Medicina, 43(2): 122126

Maulana, Heri DJ (2009). Promosi Kesehatan. Jakarta: EGC

Rasjidi I (2009). Epidemiologi Kanker Serviks. Cancer, III(3): 103-108.

Rosenstock IM (1974). Historical Origins of the Health Belief Model. Health Education \& Behavior.

Sari AP, Syahrul F (2014). Faktor yang Berhubungan dengan Tindakan Vaksinasi HPV pada Wanita Usia Dewasa. Jurnal Berkala Epidemologi, 2(3): 321-330.

Setiawati D (2014). Human Papilloma Virus Dan Kanker Serviks. Public Health Science, 450-459.

Schaefer, K.L. (2010). Beliefs and Attitudes Regarding HPV Vaccination Among College-Age Women : An Application of Health Belief Model. Disertasi. University of Maryland.

Sledge JA (2013). Contributing Factors for Human Papillomavirus (HPV) Vaccine Acceptance Among African American Young Adults. Disertasi. University of Missouri-Columbia.

Tung ILY, Machalek DA, Garland SM (2016). Attitudes, Knowledge and Factors Associated with Human Papillomavirus (HPV) Vaccine Uptake in Adolescent Girls and Young Women in Victoria, Australia.Plos One, 11(8),e0161846.doi:10.1371/journal.pone.0161846.

Wilson AR, Hashibe M, Bodson J, Gren LH, Taylor BA, Greenwood J. et al. (2016). Factors related to HPV vaccine uptake and 3-dose completion among women in a low vaccination region of the USA: An observational study. BMC Women's Health. BMC Women's Health, 16(1): 1-9. doi: 10.1186/- 
Journal of Health Promotion and Behavior (2018), 3(1): 16-26

https://doi.org/10.26911/thejhpb.2018.03.01.02

S12905-016-0323-5.

World Health Organization. (2016). UN Joint Global Programme On Cervical Cancer Prevention and Control. http://www.who.int/ncds/un-taskforce/un-joint-action-cervical-cancerleaflet.pdf. Accessed 27 April 2017. 